\title{
EFFECT OF OSCILLATING CRUDE PROTEIN CONTENT ON NITROGEN UTILIZATION, MILK PRODUCTION AND PERFORMANCE OF SHEEP
}

\author{
I.M. Khattab and A.M. Abdel-Wahed \\ Animal and Poultry Nutrition Department, Desert Research Center, El-Matareya 11753, Cairo, Egypt \\ *Corresponding author: E-mail address: khattab_drc@yahoo.com (I.M. Khattab)
}

(Received 10/6/2018, accepted $24 / 72018$ )

\section{SUMMARY}

$\mathrm{T}$ The objective of this study was to determine the effects of oscillating dietary crude protein on milk milk yield, composition, and $\mathrm{N}$ metabolism in ewes, and lambs performance. Twenty Barki ewes ewes rearing single lamb $(36.7 \pm 1.78 \mathrm{~kg}$ and $6.38 \pm 0.12 \mathrm{~kg}$ initial body weights of the ewes and and their lambs, respectively) were used in a completely randomized design during a 10-week period of lactation. Ewes were fed a diet containing different levels of crude protein, $11.2 \%$ (low), $14.1 \%$ (Medium), 17.3\% (High), or oscillating (Low and High crude protein diets oscillated for 3 days and 4 days, respectively). Dry matter intake did not differ among diets, but CP intake $(\mathrm{g} / \mathrm{d})$ differed $(P<0.05)$ from 179 (low) to 230 (medium), 272 (high), and 229 (oscillating) g/ d. However, dry matter digestibility was not varied among diets, while that of crude protein was significantly differed $(P<0.05)$ in which the highest value was for the high diet $(69.6 \%)$ and the lowest one for the low crude protein diet $(56.5 \%)$. An intermediate value was recorded for ewes fed the medium and oscillating crude protein diets (64.7\%). Nitrogen retention was higher $(P<0.05)$ in ewes fed high $(14.6 \mathrm{~g} / \mathrm{d})$ and oscillating $(12.8 \mathrm{~g} / \mathrm{d})$ diets than that in the ewes fed medium $(10.0 \mathrm{~g} / \mathrm{d})$ and low $(8.0 \mathrm{~g} / \mathrm{d})$. Urinary urea $\mathrm{N}$ not differed $(\mathrm{P}<0.05)$ between ewes fed medium $(12.1$ $\mathrm{g} / \mathrm{d})$ and oscillating $(11.6 \mathrm{~g} / \mathrm{d})$ but was lowest for those fed low $(8.2 \mathrm{~g} / \mathrm{d})$ and greatest for those fed high $(16.1$ $\mathrm{g} / \mathrm{d})$. The $\mathrm{pH}$ and total VFA values did not differ among diets, but ammonia-N differed $(P<0.05)$ from 5.11 (low) to 10.63 (medium), 14.95 (high), and $12.37 \mathrm{mg} / \mathrm{dl}$ (oscillating). Microbial protein synthesis was higher $(P<0.05)$ in ewes fed oscillating (1.69) and high (1.64) than that reported in the ewes fed medium (1.49) or low $(1.27 \mathrm{~g} / 100 \mathrm{ml}$ rumen liquid). Milk yield and composition did not differ among diets. Initial and final body weights of lambs are similar, but average daily gain $(\mathrm{g} / \mathrm{d})$ significantly $(P<0.05)$ differed $(186,194,203$ and $208 \mathrm{~g} / \mathrm{d}$ for low, medium, high and oscillating, respectively). In conclusion, these data indicated that ewes fed oscillating diet varying in crude protein concentrations had an improvement in the crude protein digestibility, microbial protein synthesis and $\mathrm{N}$ retention compared with those fed low and medium dietary protein diets.

Keywords: Sheep, nitrogen utilization, milk yield, milk composition and urea.

\section{INTRODUCTION}

Crude protein is the most expensive component and considered the key element in formulating rations for ruminants. However, more attention has been paid to control the $\mathrm{N}$ excretion by ruminants to reduce the environmental pollution (Islam et al., 2002). Excess dietary protein is usually broken down into ammonia and then lost by ruminants.

It is well-known that ruminants have low efficiency nitrogen utilization compared to the nonruminants. This low efficiency has many implications, not only for its negative effects on production performance and economic efficiency but also for the emission of contaminants to the environment. Several studies have demonstrated that feeding diets with oscillating CP concentrations on a 2-d basis can enhance nitrogen retention in growing sheep (Kiran and Mutsvangwa, 2009) and finishing cattle (Cole et al., 2003; Ludden et al., 2003). Overall, oscillating the CP concentration in growing ruminant diets can improve $\mathrm{N}$ retention and reduce $\mathrm{N}$ excretion, potentially decreasing the effects of $\mathrm{N}$ emission to the environment and increasing nitrogen utilization efficiency (NUE).

Recycling of $\mathrm{N}$ back to the rumen can increase the proportion of dietary $\mathrm{N}$ secreted in milk (Marini and Van Amburgh, 2003). Urea can be recycled back to the rumen either directly through transporters or 


\section{Khattab and Abdel-Wahed}

through the saliva (Stewart et al., 2005). The recycled urea can be degraded and used to make microbial protein may be critical for the maintenance of acceptable levels of milk and meat production by rumen bacteria and increase the NUE (Kennedy and Milligan, 1980; Reynolds and Kristensen, 2008). Ruminant microbes become more efficient in capturing recycled urea when dietary concentrations of $\mathrm{N}$ are low compared to when dietary $\mathrm{N}$ concentrations are high because of the lower amount of $\mathrm{N}$ fed and physiological changes accompanying low dietary $\mathrm{N}$ concentrations (Leng et al., 1984; Isozaki et al., 1994; Ford and Milligan, 1970).

Studies evaluating the effects of oscillating dietary CP have not been conducted with ewes. We hypothesized that oscillating dietary $\mathrm{CP}$ concentrations to equal the average concentration of a diet limited or higher in $\mathrm{CP}$ for ewes will improve milk yield and nitrogen utilization because oscillating the $\mathrm{CP}$ concentration could increase recycling of $\mathrm{N}$ back to the rumen. The objective of the experiment was to determine the effect of oscillating dietary $\mathrm{CP}$ on digestibility, performance, milk yield, and milk protein as well as $\mathrm{N}$ excretion into milk and urine.

\section{MATERIALS AND METHODS}

This study was carried out at the Maryout Research Station (located $35 \mathrm{~km}$ South West of Alexandria, Latitude $31.02^{\circ} \mathrm{N}$, Longitude $29.80^{\circ} \mathrm{C}$ ), Desert Research Center, Egypt.

\section{Animals, feeding and experimental design}

Twenty nursing Barki ewes, each with a single lamb $(36.7 \pm 1.78 \mathrm{~kg}$ and $6.4 \pm 0.12 \mathrm{~kg}$ initial body weights for the ewes and their lambs, respectively) were selected for the experiment based on lambing date. Ewes with their lambs were housed individually in shaded pens $(1.5 \mathrm{~m} \times 1 \mathrm{~m})$ and fed their diets, daily at 9:00 h. Four dietary treatments consisted of 11.2\% CP (Low), 14.1\% CP (Medium), 17.3\% CP (High), or oscillating dietary CP diets. The oscillating dietary treatment fed in two different sequences, for example 3 days of low CP followed by 4 days of high CP in a week cycle and for 10 weeks. Based on NRC (2007), the medium crude protein diet was calculated to met the crude protein requirement of lactating ewes, whereas the low and high crude protein diets were below and above crude protein requirements, respectively. however, the total crude protein intake in ewes fed the oscillating crude protein diet over a 7-d oscillating cycle as similar to that of ewes fed the medium diet. The ingredient and chemical compositions of the Low, Medium, High and Oscillating diets are presented in Table 1. Ewes were given 2 weeks for adaptation period, followed by 8 weeks for measurement period. Ewes and lambs were weighed separately biweekly before feeding throughout the study and had free access to water.

\section{Nutrient digestibility and chemical analyses}

Feed intake was recorded daily by weighting the feed leftover from the previous day. The daily samples were mixed thoroughly, composited, and then subsample for each ewe was taken. Ewes were placed on the metabolic cages at the last 10 days of the experiment: 3 days for adaptation to the metabolic cages and 7 days for collecting total faces and urine. Total daily fecal output for each ewe was collected, mixed and weighed. A daily sub-sample (10\%) was taken daily and dried at $60^{\circ} \mathrm{C}$ in a forced-air oven for $48 \mathrm{~h}$ and composited by each ewe. Feed and fecal samples were ground through a 1-mm screen and analyzed for DM, ash, and nitrogen according to AOAC (1997). Neutral detergent fiber (NDF) was determined by the procedure of Van Soest et al. (1991) without the use of an alpha-amylase but with sodium sulfite. Acid detergent fiber (ADF) was analyzed according to AOAC (1997).

For urine, a plastic bag collector was glued around the vulva of each ewe and connected to tubing that directed each day's urine to plastic container containing $5 \mathrm{ml}$ of $50 \%$ sulphuric acid. Total urine output was recorded daily. A $10 \%$ sub-sample of urine was composited by each ewe and stored at $-20^{\circ} \mathrm{C}$ until later analysis of N (AOAC, 1997) and urea-N (Paton and Crouch, 1977).

\section{Sampling and analysis of rumen fluid}

On the last day of the collection period, rumen content was sampled at $3 \mathrm{~h}$ after the morning feeding. Approximately $100 \mathrm{ml}$ of rumen fluid were collected manually from the ventral sac by using a stomach tube, strained through 4 layers of cheesecloth. The $\mathrm{pH}$ of rumen fluid was measured immediately with a pH meter (Accumet Model 15, Fisher Scientific, USA). A $50 \mathrm{ml}$ was immediately acidified with $2.5 \mathrm{ml}$ of $6 \mathrm{~N} \mathrm{HCl}$ and frozen $\left(-20^{\circ} \mathrm{C}\right)$ for subsequent determination of ammonia-N concentration (AOAC, 1997), and total volatile fatty acid analysis by titration, after steam distillation of a 5-mL sample (Annison, 1954). 
The method of tungstic acid (TA) - sulphuric acid precipitation was used to determine microbial protein synthesis in rumen liquid according to winter et. al. (1964) as follow: a $16 \mathrm{ml}$ of filtrated fluid was added to $4 \mathrm{ml}$ of $10 \%$ (wt/vol) sodium tungstate and $4 \mathrm{ml}$ of $1.07 \mathrm{~N}$ sulfuric acid. After allowing the tubes to stand at $5^{\circ} \mathrm{C}$ for $4 \mathrm{~h}$, the samples were centrifuged at $9,000 \times \mathrm{g}$ for $15 \mathrm{~min}$., and the supernatant was analyzed for TA $\mathrm{N}$.

Table (1): Ingredients and chemical composition of experimental diets (\% DM basis).

\begin{tabular}{|c|c|c|c|}
\hline Item & Low & Medium & High \\
\hline \multicolumn{4}{|l|}{ Ingredients } \\
\hline Berseem hay & 50 & 50 & 50 \\
\hline Corn grain & 33.7 & 26.7 & 19.7 \\
\hline Soybean meal & 0 & 8 & 17 \\
\hline Wheat bran & 14.6 & 13.6 & 11.6 \\
\hline Limestone & 0.9 & 0.9 & 0.9 \\
\hline Salt & 0.5 & 0.5 & 0.5 \\
\hline Vitamin mineral premix ${ }^{1}$ & 0.3 & 0.3 & 0.3 \\
\hline \multicolumn{4}{|l|}{ Chemical composition } \\
\hline $\mathrm{DM}$ & 92.8 & 92.7 & 92.2 \\
\hline $\mathrm{OM}$ & 89.6 & 90 & 90.7 \\
\hline $\mathrm{CP}$ & 11.2 & 14.1 & 17.3 \\
\hline NDF & 37 & 38.6 & 38 \\
\hline $\mathrm{ADF}$ & 27.5 & 26.7 & 27.6 \\
\hline $\mathrm{NE}^{2}$ (Mcal/ kg) & 1.49 & 1.50 & 1.51 \\
\hline $\begin{array}{l}{ }^{1} \text { composition } / \mathrm{kg} \text { vitamin min } \\
6.7 \mathrm{~g} \text { of } \mathrm{Cu} ; 18.7 \mathrm{~g} \text { of } \mathrm{Fe} ; 20 \\
\text { vitamin } \mathrm{E} \text {. }\end{array}$ & $\begin{array}{l}a ; 6.0 \\
0,0001\end{array}$ & $\begin{array}{l}M g ; 0.2 g \\
1,000,000\end{array}$ & $\begin{array}{l}S e ; 1.7 \& \\
3,3,000\end{array}$ \\
\hline
\end{tabular}

\section{Sampling and analysis of blood plasma}

A blood sample (about $10 \mathrm{~mL}$ ) was collected from a jugular vein (at the same time as rumen fluid sampling) into tubes containing EDTA, and plasma was separated by centrifugation at $3000 \times g$ for $10 \mathrm{~min}$. and stored at $-20^{\circ} \mathrm{C}$ until analysis of plasma urea $\mathrm{N}$ according to the method of Crocker (1967).

\section{Milk sampling and milk composition}

After the adaptation period (i.e., two weeks), milk measurements were taken weekly for the following six weeks. Prior to milking, lambs were separated from their dams for 12 hours overnight ( $8 \mathrm{pm}-8 \mathrm{am})$ and were only reintroduced to their dams after milking. Milk yield was recorded. Milk yield was then multiplied by 2 to calculate daily milk yield and, consequently, multiplied by 60 days to calculate milk intake $\mathrm{kg}$ / lamb. Milk samples were analyzed for fat, protein, and lactose using infrared spectrophotometry (Foss 120 Milko-Scan, Foss Electric, Hillerød, Denmark).

\section{Statistical analyses}

Statistical analysis for the obtained data was carried out using the general linear model producers of SAS (SAS Inst. Inc. Cary, NC, 2008) in a complete randomized design. Comparison among means was carried out using Fisher's least significant difference test. Treatment effects were considered significant at $P<0.05$.

\section{RESULTS AND DISCUSSION}

As mentioned in the materials and methods section, the experimental diets had a similar composition of nutrients but with different CP concentrations (Tables 1).

Intakes and digestibility of DM, OM, $\mathrm{CP}, \mathrm{NDF}$ and $\mathrm{ADF}$ are presented in Table (2). Ewes fed the oscillating diet had similar DM and OM intake when compared to those fed the low, medium or high CP diets. It is likely that DM intake was not differed among diets because of the restricted feeding. Also, no 


\section{Khattab and Abdel-Wahed}

significant differences existed among diets in digestibility of DM and OM. Our results agree with Cole (1999) who reported that DM digestibility was not affected by oscillating dietary protein concentrations in lambs between 10 and $15 \%$ at 24-h or 48-h intervals, and with Ludden et al. (2002) in lambs fed a diet, containing a different CP concentration between 13 and $17 \%$ at 48 -h intervals. Moreover, kiran and Mutsvangwa (2009) demonstrated that oscillating dietary protein concentrations between 7.5 and $13.5 \%$ on $48 \mathrm{~h}$ basis in lambs did not affect DM digestibility.

Intakes of NDF and ADF did not differ $(\mathrm{P}<0.05)$ between diets (Table 2). Digestibility of NDF and ADF were different $(\mathrm{P}<0.05)$ in ewes fed oscillating and high $\mathrm{CP}$ diets compared to those fed low and medium diets. In our experiment, fiber digestibility was increased with increasing dietary crude protein and with oscillating treatment. This increase may be related with greater nitrogen availability for fiber fermentation. Similarly, Ludden et al. (2002) and kiran and Mutsvangwa (2009) reported that NDF and ADF digestibilities were affected by increasing dietary protein concentrations in lambs.

Table (2): Nutrient intake and digestibility for ewes fed low, medium, high and oscillating dietary crude protein content.

\begin{tabular}{|c|c|c|c|c|c|c|}
\hline \multirow[t]{2}{*}{ Item } & \multicolumn{4}{|c|}{ Diet } & \multirow[t]{2}{*}{ SEM } & \multirow[t]{2}{*}{$P$-value } \\
\hline & Low & Medium & High & Oscillating & & \\
\hline \multicolumn{7}{|c|}{ Nutrient intake, g/d } \\
\hline DM & 1600 & 1649 & 1577 & 1600 & 29.04 & 0.8923 \\
\hline $\mathrm{OM}$ & 1434 & 1473 & 1431 & 1450 & 26.29 & 0.9627 \\
\hline $\mathrm{CP}$ & $179^{\mathrm{c}}$ & $230^{\mathrm{b}}$ & $272^{\mathrm{a}}$ & $229^{\mathrm{b}}$ & 9.86 & 0.0181 \\
\hline NDF & 593 & 631 & 599 & 603 & 11.31 & 0.7305 \\
\hline $\mathrm{ADF}$ & 440 & 436 & 443 & 442 & 7.92 & 0.9832 \\
\hline \multicolumn{7}{|c|}{ Digestibility, \% } \\
\hline DM & 65.70 & 66.32 & 68.24 & 66.71 & 0.45 & 0.3397 \\
\hline $\mathrm{OM}$ & 68.05 & 68.18 & 70.81 & 69.30 & 0.42 & 0.1293 \\
\hline $\mathrm{CP}$ & $56.45^{\mathrm{c}}$ & $63.32^{\mathrm{b}}$ & $69.56^{\mathrm{a}}$ & $64.67^{\mathrm{b}}$ & 1.53 & 0.0140 \\
\hline NDF & $43.35^{\mathrm{b}}$ & $43.40^{\mathrm{b}}$ & $46.66^{\mathrm{a}}$ & $47.80^{\mathrm{a}}$ & 0.68 & 0.0472 \\
\hline $\mathrm{ADF}$ & $34.76^{\mathrm{b}}$ & $36.05^{\mathrm{ab}}$ & $39.87^{\mathrm{a}}$ & $39.53^{\mathrm{a}}$ & 0.67 & 0.0455 \\
\hline
\end{tabular}

Ewes fed high $\mathrm{CP}$ diet had a higher $(\mathrm{P}<0.05)$ in $\mathrm{CP}$ intake and digestibility compared to those fed medium and oscillating CP diets, then low diet recorded the lowest value (Table 2).

Nitrogen utilization values are presented in Table (3). Nitrogen intake and urinary $\mathrm{N}$ execration $(\mathrm{g} / \mathrm{d})$ were greater $(\mathrm{P}<0.05)$ for the ewes fed high compared to those fed oscillating, medium, and low $\mathrm{CP}$ diets.

Table (3): Nitrogen utilization in ewes fed low, medium, high and oscillating dietary crude protein content.

\begin{tabular}{|c|c|c|c|c|c|c|}
\hline \multirow[t]{2}{*}{ Item } & \multicolumn{4}{|l|}{ Diet } & \multirow[t]{2}{*}{ SEM } & \multirow[t]{2}{*}{$P$-value } \\
\hline & Low & Medium & High & Oscillating & & \\
\hline \multicolumn{7}{|l|}{$\mathrm{N}$ utilization, $\mathrm{g} / \mathrm{d}$} \\
\hline $\mathrm{N}$ intake & $28.66^{\mathrm{c}}$ & $36.83^{\mathrm{b}}$ & $43.75^{\mathrm{a}}$ & $36.65^{\mathrm{b}}$ & 0.79 & 0.0083 \\
\hline Fecal N & 12.45 & 13.82 & 12.91 & 12.25 & 0.27 & 0.3930 \\
\hline Urine $\mathrm{N}$ & $8.24^{\mathrm{c}}$ & $13.22^{\mathrm{ab}}$ & $16.09^{\mathrm{a}}$ & $11.56^{\mathrm{b}}$ & 0.83 & 0.0018 \\
\hline $\mathrm{N}$ retention & $7.98^{\mathrm{b}}$ & $9.95^{\mathrm{b}}$ & $14.57^{\mathrm{a}}$ & $12.84^{\mathrm{a}}$ & 0.63 & 0.0246 \\
\hline $\mathrm{N}$ retention $\% \mathrm{~N}$ intake & $16.61^{\mathrm{c}}$ & $23.32^{\mathrm{b}}$ & $30.66^{\mathrm{a}}$ & $24.40^{\mathrm{b}}$ & 0.83 & 0.0169 \\
\hline
\end{tabular}

Ewes fed high and oscillating $\mathrm{CP}$ diets had a greater $(\mathrm{P}<0.05)$ nitrogen retention $(\mathrm{g} / \mathrm{d})$ compared with those fed the medium and low CP diets. Results are going with those reported in Table (2) for the digestibility trail. In agreement, previous studies showed that oscillation of the dietary CP improved N retention in ruminants (Collins and Pritchard, 1992; Cole, 1999; Cole et al., 2003). This improvement in 
the $\mathrm{N}$ retention may provide a viable means to reduce the release of $\mathrm{N}$, especially ammonia, into the environment. Cole (1999) hypothesized that the improvement in $\mathrm{N}$ retention by oscillating the dietary CP is due to improved recycling of $\mathrm{N}$ to the rumen in the form of urea, stimulating the increase in total entry of urea $\mathrm{N}$ back to the gastrointestinal tract.

Values of $\mathrm{pH}$, ammonia-N, total VFA, microbial protein, urinary urea and plasma urea are presented in Table (4). The $\mathrm{pH}$ and total VFA values were not varied among treatments. Ammonia-N and microbial protein synthesis were higher $(\mathrm{P}<0.05)$ in ewes fed the high and oscillating diets compared to the low $\mathrm{CP}$ diet, while an intermediate values were recorded for those fed the medium diet. The effects of feeding oscillating dietary protein levels compared to feeding static dietary $\mathrm{CP}$ on microbial protein production in ewes is the primary objective of the current study. Microbial protein flow to the small intestine was higher in ewes fed the oscillating diet compared to those fed the medium diet, although a similar CP intake was recorded for ewes fed both diets (Table 2). Cole (1999) reported that the improvement in $\mathrm{N}$ retention observed in ruminants when dietary $\mathrm{CP}$ was oscillated could be due to the stimulating for the increased urea-N recycling, where it (urea-N) can potentially increase intestinal microbial protein supply. Although we did not measure the incorporation of recycled urea into microbial protein, microbial protein was greater in ewes fed the oscillating compared with those fed the medium diet.

Table (4): Rumen metabolites, microbial protein, urinary urea and plasma urea in ewes fed low, medium, high and oscillating dietary crude protein content.

\begin{tabular}{lcccccc}
\hline \multirow{2}{*}{ Item } & \multicolumn{3}{c}{ Diets } & SEM & $P$-value \\
\cline { 2 - 6 } & Low & Medium & High & Oscillating & \\
\hline $\mathrm{pH}$ & 6.32 & 6.28 & 6.49 & 6.32 & 0.04 & 0.2131 \\
$\mathrm{NH}_{3}-\mathrm{N}, \mathrm{mg} / \mathrm{dl}$ & $5.11^{\mathrm{b}}$ & $10.63^{\mathrm{ab}}$ & $14.95^{\mathrm{a}}$ & $12.37^{\mathrm{a}}$ & 1.19 & 0.0425 \\
Total VFA, mg/ dl & 3.87 & 3.99 & 4.58 & 4.40 & 0.13 & 0.2411 \\
Microbial protein g/ 100 ml rumen liquid & $1.27^{\mathrm{c}}$ & $1.49^{\mathrm{b}}$ & $1.64^{\mathrm{a}}$ & $1.69^{\mathrm{a}}$ & 0.05 & 0.0371 \\
Urinary urea-N, g/d & $7.87^{\mathrm{c}}$ & $12.06^{\mathrm{b}}$ & $17.10^{\mathrm{a}}$ & $11.24^{\mathrm{b}}$ & 0.83 & 0.0010 \\
Plasma urea-N, mg/dl & $12.45^{\mathrm{c}}$ & $30.81^{\mathrm{b}}$ & $46.23^{\mathrm{a}}$ & $29.04^{\mathrm{b}}$ & 0.88 & 0.0029 \\
\hline a,b,c means within a row with different superscripts differ $(P<0.05)$. SEM: Standard error of means. &
\end{tabular}

On the other hand, ewes fed the high dietary protein diet had a higher $(\mathrm{P}<0.05)$ urinary urea- $\mathrm{N}$ and plasma urea-N (Table 4), when compared to those fed the oscillating and medium CP diets. Our results are in agreement with the findings of Cole (1999) and kiran and Mutsvangwa (2009). These observations are likely attributable to the higher $\mathrm{N}$ intakes that were observed in ewes fed the high diet compared to those fed the oscillating and medium CP diet. A similar CP intake (Table 2) and similar values for urea $\mathrm{N}$ in urine or plasma were observed for ewes fed medium and oscillating CP diets that are in agreement with Cole (1999) and Archibeque et al. (2007).

Milk yield and milk composition are presented in Table (5). Milk yield (g/ 12h) and its composition, fat, protein, and lactose, were similar among dietary treatments. Also, there were no differences among diets regarding to milk composition (\%).

Table (5): Milk yield and milk composition in ewes fed low, medium, high and oscillating dietary crude protein content.

\begin{tabular}{lcccccc}
\hline Item & \multicolumn{9}{c}{ Diets } & SEM & $P$-value \\
\cline { 2 - 5 } & Low & Medium & High & Oscillating & & \\
\hline Milk, g/ 12 h & & & & & & \\
$\quad$ Yield & 234 & 257 & 297 & 285 & 10.31 & 0.1705 \\
$\quad$ Fat & 7.44 & 9.43 & 10.85 & 9.67 & 0.45 & 0.1073 \\
$\quad$ Protein & 9.84 & 11.21 & 13.64 & 13.74 & 0.67 & 0.1149 \\
$\quad$ Lactose & 13.75 & 12.95 & 16.07 & 16.30 & 0.66 & 0.1946 \\
Milk composition, \% & & & & & & \\
$\quad$ Fat & 3.19 & 3.73 & 3.69 & 3.36 & 0.10 & 0.2342 \\
$\quad$ Protein & 4.22 & 4.37 & 4.61 & 4.72 & 0.10 & 0.2896 \\
$\quad$ Lactose & 5.93 & 5.06 & 5.38 & 5.77 & 0.18 & 0.3970 \\
\hline
\end{tabular}

SEM: Standard error of means. 
Performance of ewes and lambs are presented in Table (6). Similar initial or final body weight for ewes and lambs was reported. Lambs fed the high and oscillating diets had higher $(\mathrm{P}<0.05)$ milk intake $(\mathrm{kg} / \mathrm{lamb})$ when compared to those fed the medium and low diets. Average daily gain of the lambs in oscillating diet had higher $(\mathrm{P}<0.05)$, when compared to those in the low diet. Lambs in the medium and high diets had intermediate. The effects of oscillating dietary crude protein on performance in the present study tend to agree with results of Kiran and Mutsvangwa (2009), who also noted numerically greater average daily gain in lambs fed oscillating crude protein concentrations than in lambs fed the same quantity of crude protein on a continuous basis.

Table (6): Performance of lambs and ewes fed low, medium, high and oscillating dietary crude protein content.

\begin{tabular}{|c|c|c|c|c|c|c|}
\hline \multirow[t]{2}{*}{ Item } & \multicolumn{4}{|c|}{ Diet } & \multirow[t]{2}{*}{ SEM } & \multirow[t]{2}{*}{$P$-value } \\
\hline & Low & Medium & High & Oscillating & & \\
\hline No. of ewes & 5 & 5 & 5 & 5 & & \\
\hline Initial weight, kg & 38.76 & 38.36 & 39.16 & 38.06 & 1.78 & 0.4545 \\
\hline Final weight, kg & 36.98 & 37.78 & 37.92 & 38.76 & 0.49 & 0.6467 \\
\hline No. of lambs & 5 & 5 & 5 & 5 & & \\
\hline Milk intake, $\mathrm{kg} /$ lamb & $28.03^{\mathrm{b}}$ & $30.82^{\mathrm{ab}}$ & $35.60^{\mathrm{a}}$ & $34.22^{\mathrm{a}}$ & 1.24 & 0.0494 \\
\hline Initial weight, kg & 6.36 & 6.46 & 6.08 & 6.62 & 0.12 & 0.8557 \\
\hline Final weight, $\mathrm{kg}$ & 17.54 & 18.08 & 18.24 & 19.08 & 0.27 & 0.2419 \\
\hline Average daily gain, $\mathrm{g} / \mathrm{d}$ & $186^{\mathrm{b}}$ & $194^{\mathrm{ab}}$ & $203^{\mathrm{ab}}$ & $208^{\mathrm{a}}$ & 2.72 & 0.0130 \\
\hline
\end{tabular}

${ }^{a, b}$ means within a row with different superscripts differ $(P<0.05)$. SEM: Standard error of means.

\section{CONCLUSIONS}

In conclusion, compared to feeding the same $\mathrm{CP}$ diet on a daily basis, feeding oscillating dietary $\mathrm{CP}$ concentrations (low and high) in a week cycle improves the CP utilization by nursing ewes in which the digestibility of $\mathrm{CP}$, microbial protein synthesis, and $\mathrm{N}$ retention were significantly greater in comparison with those reported by ewes fed a similar CP intake (medium diet).

\section{REFERENCES}

Annison, E.F. (1954). Studies on the volatile fatty acids of sheep blood with special reference to formic acid. Biochemical Journal. 58(4): 670-680.

AOAC (1997). Association of Official Analytical Chemists. Official Methods of Analysis, $16^{\text {th }}$ ed. AOAC, Arlington, VA, USA.

Archibeque, S.L.; H.C.Freetly and C.L. Ferrell (2007). Net portal and hepatic flux of nutrients in growing wethers fed high concentrate diets with oscillating protein concentrations. Journal of Animal Science. 85: 997-1005.

Cole, N.A. (1999). Nitrogen retention by lambs fed oscillating dietary protein concentrations. Journal of Animal Science. 77:215-22.

Cole, N.A.; L.W. Greene; F.T. McCollum; T. Montgomery and k. McBride (2003). Influence of oscillating dietary protein concentration on performance, acid-base balance, and nitrogen excretions of steers. Journal of Animal Science. 81: 2660-2668.

Collins, R. M. and R. H. Pritchard (1992). Alternate day supplementation of corn stalk diets with soybean meal or corn gluten meal fed to ruminants. Journal of Animal Science. 70:3899-3908.

Crocker C.L. (1967). Rapid determination of urea nitrogen in serum or plasma without deproteinization. American Journal of Medical Technology. 33(5):361-5. 
Ford, A.L. and L.P. Milligan (1970). Tracer studies of urea recycling in sheep. Canadian Journal of Animal Science. 50:129-135.

Islam, M. R.; M. Ishida; S. Ando and T. Nishida (2002). In situ dry matter, nitrogen and phosphorous disappearance of different feeds for ruminants. Asian-Aust. Journal of Animal Science. 15:793-799.

Isozaki, T.; A.G. Gillin; C.E. Swanson and J.M. Sands (1994). Protein restriction sequentially induces new urea transport processes in rat initial IMCD. American Journal of Physiology-Renal Physiology. 266: F756-F761.

Kennedy, P.M. and L.P. Milligan (1980). The degradation and utilization of endogenous urea in the gastrointestinal tract of ruminants: a review. Canadian Journal of Animal Science. 60:205-210.

Kiran D. and T. Mutsvangwa (2009). Nitrogen utilization in growing lambs fed oscillating dietary protein concentrations. Animal Feed Science and Technology. 52:33-41.

Leng, L.; M. Szanyiová and K. Boda (1984). The renal response of sheep to a low dietary nitrogen intake. Physiologia Bohemoslovaca. 34:147-154.

Ludden, P.A.; T.L. Wechter and B. W. Hess (2002). Effect of oscillating dietary protein on nutrient digestibility, nitrogen metabolism, and gastrointestinal organ mass in sheep. Journal of Animal Science. 80, 3021-3026.

Ludden, P.A.; T.L. Wechter; E.J. Scholljegerdes and B. W. Hess (2003). Effect of oscillating dietary protein on growth, efficiency, and serum metabolites in growing beef steers. The Professional Animal Scientist. 19: 30-34.

Marini, J.C. and M.E. Van Amburgh (2003). Nitrogen metabolism and recycling in Holstein heifers. Journal of Animal Science. 81:545-552.

NRC (2007). National Research Council. Nutrient Requirements of Small Ruminants: Sheep, Goats, Cervids and New World Camelids. ${ }^{\text {st }}$ Ed. National Academy Press, Washington, USA.

Paton, C.J. and S.R. Crouch (1977). Determination of urea. Analytical Chemistry. 49 (3): 464-469.

Reynolds, C.K. and N.B. Kristensen (2008). Nitrogen recycling through the gut and the nitrogen economy of ruminants: An asynchronous symbiosis. Journal of Animal Science. 86 (E. Suppl.): E293-E305.

SAS Institute (2008). SAS/STAT 9.2 User's Guide, SAS Institute Inc., Cary, NC.

Stewart G.S.; C. Graham; S.S.Cattell; T.P.L.Smith; N.L. Simmons and C.P. Smith (2005). UT-B is expressed in bovine rumen: Potential role in ruminal urea transport. American Journal of Physiology Regulatory, Integrative and Comparative Physiology. 289 (2): R605-R612.

Van Soest, P.J.; J.B. Robertson and B.A. Lewis (1991). Methods for dietary fiber, neutral detergent fiber and non-starch polysaccharides (NSP) in relation to animal nutrition. Journal of Dairy Science. 74:3583-3597.

Winter K.A.; R.R. Johnson and B.A. Dehority (1964). Metabolism of urea nitrogen by mixed cultures of rumen bacteria grown on cellulose. Journal of Dairy Science. 47(7): 793-797. 


\section{Khattab and Abdel-Wahed}

\section{تأثير تذبذب محتوي البروتين الخام على الاستفادة من النيتروجين، انتاج اللبن والآداء في الأغنام}

إبراهيم محم خطاب و عادل محمد عبد الواحد

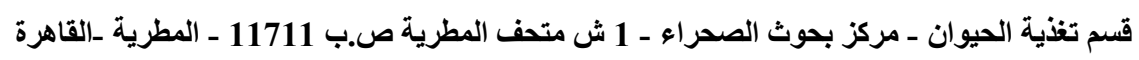

اجريت هذه التجربة لار اسة تأثير تذبذب البروتين الخام في علائق الاغنام على إنتاج و التركيب الكيماوي للبن والإستفادة من النيتروجين

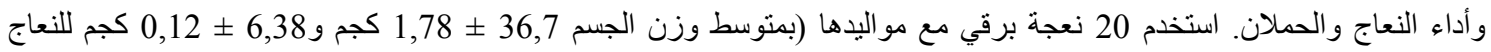

و الحملان على التو الي) قسمت فى الدراسة الى أربع مجمو عات وغذيت تغذية فردية لعلي إحدى العلائق التجريبية الأربعة الأثية:

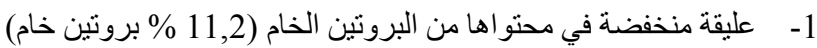

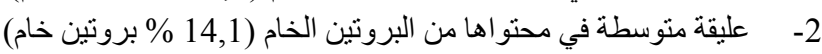

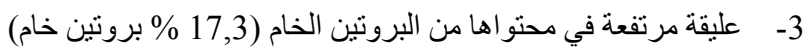

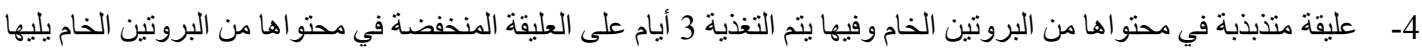

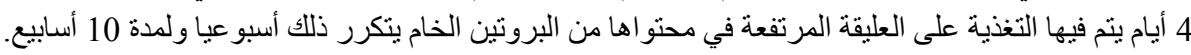

$$
\text { وكانت النتائج كالتالي: }
$$

1- لم تكن هناك فروق معنوية بين العلائق على كمية المادة الجافة المأكولة، في حين اختلفت كمية البروتين الخام المأكولة وتراوحت

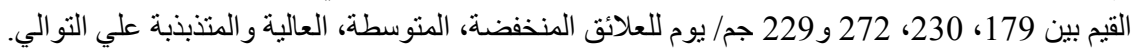

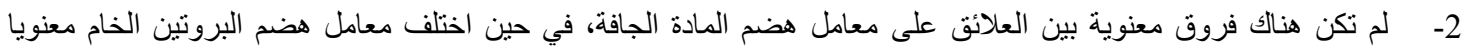

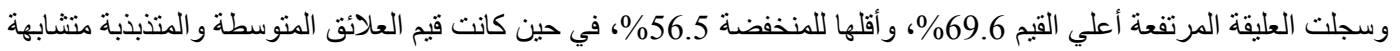
ومنوسطة 63,3 و64,7\% على على التو الي.

3- كية النيتروجين المحتجز جم/23,3 ايوم كان أعلي في النعاج المغذاة على العليقة المرتفعة والمتذبذبة بالمقارنة بالنعاج المغذاة علي

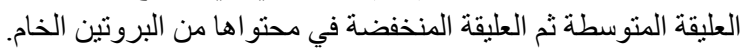

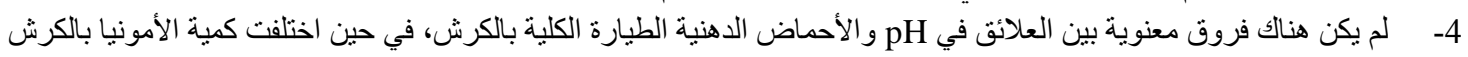

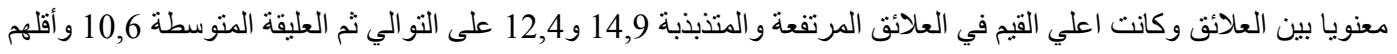

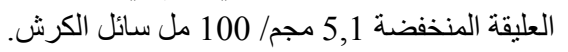
5- ارتفعت معنويا كمية البروتين الميكروبي المنتج في الكرش في العلائق المتذبذبة والمرتفعة 1,7 و1,6 علي التو الي ثم العليقة

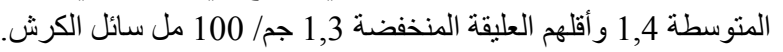

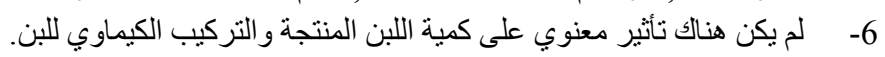

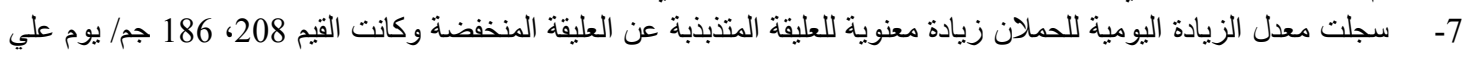
التو الي، في حين كانت للعلائق العالية والمتوسطة قيم منوسطة 203، 194 جم/ يوم علي التو الي.

و وعلى ذلك تثير النتائج الي أن العليقة المتذبذبة في مستويات البروتين الخام أدت الي تحسن في معامل هضم البروتين، معدل تخليق

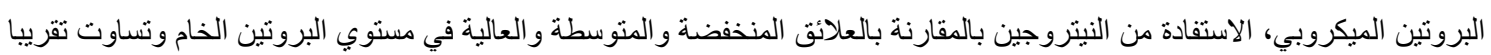
مع العليقة المرتفعة فى مستوى البروتين. 